\section{OCCURRENCE OF LISTERIA SPECIES IN DIFFERENT CAPTIVE WILD ANIMALS OF NANDANKANAN ZOO, BARANGA, ODISHA, INDIA}

\author{
Laxmi Narayan Sarangi ${ }^{1}$ \& Hemanta Kumar Panda ${ }^{2}$ \\ ${ }^{1,2}$ Department of Bacteriology and Virology, College of Veterinary Science and Animal Husbandry, Odisha University of Agriculture and \\ Technology, Bhubaneswar, Odisha 751003, India \\ ${ }^{1}$ laxmisarangi@gmail.com (corresponding author), ${ }^{2}$ drpanda.hk@gmail.com
}

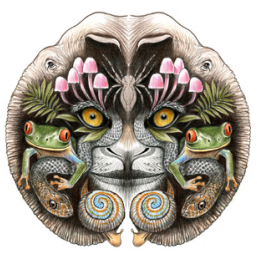

ISSN

Online 0974-7907

Print 0974-7893

OPEN ACCESS
Abstract: Listeria species were isolated from faecal samples collected from different captive wild animals of Nandankanan Zoo, Baranga, Odisha, using selective enrichment medium. The isolates were characterized based on their cell morphology, biochemical and sugar fermentation characteristics as well as culture morphology. Further, in vitro and in vivo pathogenicity tests were carried out to assess the pathogenic potential of the isolates. Listeria were found in 24 $(23.07 \%)$ of the total 104 faecal samples. Listeria were isolated from the samples of tiger, bear, hyena, leopard, zebra, elephant, jackal, lion, barking deer, porcupine, chital, monkey and wild boar. Out of the 24 Listeria isolates 11 were confirmed as L. monocytogenes. The other 13 isolates included $L$. innocua, L. seeligeri, L. welshimeri and $L$. ivanovii. The pathogenicity study revealed that only four isolates were pathogenic. Three of these were L. monocytogenes isolated from tiger, hyena and elephant and one was $L$. ivanovii isolated from leopard. Antibiotic sensitivity of the 24 isolates was high towards ciprofloxacin, levofloxacin, amoxicillin, azithromycin and enrofloxacin. The isolates showed resistance towards oxytetracyclin, gentamicin, cephadroxil, penicillin- $\mathrm{G}$ and nalidixic acid.

Keywords: Captive wild animals, Listeria, L. monocytogenes, L. ivanovii, Nandankanan Zoo, Prevalence.

Listeriosis is an important emerging zoonotic disease caused by pathogenic strains of Listeria species particularly L. monocytogenes and L. ivanovii. The disease is distributed worldwide and has been reported in countries of six continents. The significance of the pathogen lies in its ubiquitous nature (Low \& Donachie
1997) and wide host range, which includes 40 mammals, 20 birds, crustaceans, ticks and fishes (Sonnenworth 1980). The organism is commonly found in water, soil, vegetative materials and faecal samples of animals (Sheehan et al. 1994). The pathogenic potential of Listeria is well known as it causes abortion, mastitis, infertility, encephalitis and septicaemia in animals, but its spectrum of diseases is much broader and ranges from asymptomatic infection and silent carriage to cutaneous lesions or infections like conjunctivitis, urethritis, endocarditis, pneumonia, pericarditis and disturbance in gait, followed by death (Malik et al. 2010).

The number of animals in the wild is decreasing rapidly and many of the animals living in zoos represent endangered species. Proper care and management of such animals must be of prime importance. There is a high risk of infection to the captive animals in zoos as large numbers of animals are kept in a restricted area (Bowens et al. 2003). Listeria spp. have the ability to survive for a long period in the soil and are also possibly excreted in the faeces of asymptomatic carrier animals and pose a great risk of infection to other animals, zoo keepers and also to the visitors. This study was undertaken to determine the occurrence of Listeria

DOI: http://dx.doi.org/10.11609/JoTT.03175.122 | ZooBank: urn:Isid:zoobank.org:pub:A028441D-1331-4166-9B50-905712F50184

Editor: Ulrike Streicher, Fauna \& Flora International, Hanoi, Vietnam.

Date of publication: 26 January 2013 (online \& print)

Manuscript details: Ms \# 03175 | Received 22 April 2012| Final received 11 December 2012 | Finally accepted 29 December 2012

Citation: Sarangi, L.N. \& H.K. Panda (2013). Occurrence of Listeria species in different captive wild animals of Nandankanan Zoo, Baranga, Odisha, India. Journal of Threatened Taxa 5(1): 3542-3547; doi:10.11609/JoTT.o3175.122

Copyright: (C) Sarangi \& Panda 2013. Creative Commons Attribution 3.0 Unported License. JoTT allows unrestricted use of this article in any medium, reproduction and distribution by providing adequate credit to the authors and the source of publication.

Funding: The facilities was provided by OUAT, Bhubaneswar at department of Microbiology, C.V.Sc. \& A.H., OUAT. No external funding was availed for this work.

Competing Interest: Authors declare that they have no competing interest.

Acknowledgements: The authors are thankful to Chief Wildlife Warden, Odisha, Director, Nandankanan Zoological park, Baranga for necessary permission to carry out the research work, Dean, Odisha Veterinary College, for providing necessary facilities, Senior Veterinary Officer, Veterinary Assistant Surgeon and staffs of Nandankanan Veterinary Hospital and zoo keepers for their kind help and cooperation during sample collection and also to Dr. Lala A.K. Singh, Senior Research Officer at Government of Orissa, Dr. S.V.S. Malik, Principal Scientist, Division of VPH, I.V.R.I., Izatnagar and Dr. A. Dalai, Former Director, Department of Biotechnology, Ravenshaw University for their valuable suggestions and kind help during the course of the study. 
species in faecal samples of wild animal species in the Nandankanan Zoo, Baranga, Odisha, India.

\section{Materials and Methods}

Test strains: The standard strains of Listeria monocytogenes (MTCC 1143), Listeria ivanovii (MTCC 7056), Staphylococcus aureus (MTCC 1144) and Rhodococcus equi (MTCC 1135) were obtained from the Microbial Type Culture Collection and Gene Bank (MTCC), Institute of Microbial Technology (IMTECH), Chandigarh, India. The strains were tested for their purity as well as for their morphological and biochemical characteristics. The L. monocytogenes strain was also tested for its pathogenicity in vitro and in vivo. All the strains were maintained by sub culturing them in Brain Heart Infusion (BHI) at 15 days interval.

Collection of samples: One hundred and four faecal samples were either collected from an individual animal, if it was kept in a separate enclosure (noted as individual samples) or from several animals if they were housed together in one enclosure (noted as pooled samples). All the samples were collected in the morning hours non invasively (Table 1).

Isolation method and media used: Listeria were isolated per USDA method described by McClain \& Lee (1988) with slight modifications. Therefore, the samples were enriched in a two-step enrichment procedure and were then plated onto a selective medium as follows.

The swabs were directly transferred into sterile test tubes containing University of Vermont Medium 1 (UVM-1, Hi-Media) and were incubated at $37^{\circ} \mathrm{C}$ for $24 \mathrm{hr}$. $0.1 \mathrm{ml}$ of the enriched inoculum was then transferred to University of Vermont Medium 2 (UVM-2, Hi-Media) and incubated at $37^{\circ} \mathrm{C}$ for $48 \mathrm{hr}$. The enriched medium was streaked on Polymyxin Acriflavin Lithium chloride Ceftazidime Esculin Mannitol agar (PALCAM, Hi-Media). The streaked plates were incubated at $37^{\circ} \mathrm{C}$ for $48 \mathrm{hr}$. The typical grey-green colonies with black centre and a black halo around the colonies were presumptively identified to be Listeria.

Confirmation of the isolates: The isolates were characterized by cell morphology, Gram's staining, catalase test, oxidase test, tumbling motility at 20-25 ${ }^{\circ} \mathrm{C}$, MR-VP test, DLABN test and fermentation of sugar [rhamnose, xylose, maltose and mannitol] (Seeliger \& Jones 1986; Low \& Donachie 1997). In vitro pathogenicity was tested with blood agar and Christie, Atkin, MunchPetersen (CAMP) test with Staphylococcus aureus and Rhodococcus equi. In vivo pathogenicity was tested by inoculating mice and chicken embryos.

\section{In vitro pathogenicity tests}

Haemolysis on sheep blood agar (SBA) plate: Listeria isolates were tested for the type and degree of haemolysis on SBA. Detection of haemolysin allows to discriminate between virulent and avirulent Listeria species. The isolates were streaked onto SBA plates, incubated at $37^{\circ} \mathrm{C}$ in a humidified chamber for $24 \mathrm{hr}$ and examined for haemolytic zones around the colonies. The characteristic wide and clear zone of $\beta$-haemolysis suggested L. ivanovii, while a narrow zone of $\beta$-haemolysis was characteristic for L. monocytogenes (McKellar, 1994).

Christie, Atkin, Munch-Petersen (CAMP) test: CAMP test was conducted following the standards of the Bureau of Indian Standards (BIS 1994) with some modifications. The standard strains of Staphylococcus aureus and Rhodococcus equi were cultured for $24 \mathrm{hr}$ on SBA plates at $37^{\circ} \mathrm{C}$. The cultured inoculates of each strain were streaked onto freshly prepared 7\% SBA plates in parallel streaks with considerable space between streaks. Afterwards, the Listeria isolates were streaked onto these plates at $90^{\circ}$ angle and $3 \mathrm{~mm}$ apart from $S$. aureus and $R$. equi streaks. The inoculated plates were incubated at $37^{\circ} \mathrm{C}$ for $24 \mathrm{hr}$. The plates were examined for enhancement of haemolytic zone; in case of a CAMPpositive reaction the haemolytic zone between a Listeria strain and the $S$. aureus or $R$. equi strain was enhanced due to the synergistic effect of their haemolysins. All the Listeria isolates with CAMP-positivity against $S$. aureus or $R$. equi were characterized as L. monocytogenes and L. ivanovii respectively (McKellar 1994).

\section{In vivo pathogenicity tests}

Mice inoculation test: The pathogenicity of the Listeria isolates was tested by inoculating mice according to the method described by Menudier et al. (1991) with suitable modifications. The test isolates of Listeria were grown on Brain Heart Infusion (BHI) slants at $37^{\circ} \mathrm{C}$ for $24 \mathrm{hr}$. The bacterial growth was harvested with sterile normal saline solution (NSS) and the opacity of solution was adjusted to McFarland Nephelometric tube number 1. Mice of either sex weighing 18-20 g were inoculated intraperitoneally with a volume of $0.4 \mathrm{ml}$ of the solutions containing approximately $10^{7}$ colony forming units (cfu) of the test organism per $\mathrm{ml}$. The inoculated mice were observed for mortality over a period of $72 \mathrm{hr}$.

Chick embryo inoculation test: The pathogenicity of Listeria isolates was also tested by inoculating chicken embryos following the method described by Notermans et al. (1991). The blood vessel-free surface of the chorioallantoic membrane (CAM) of two precandled 10day old embryonated chicken eggs was inoculated with 
Table 1. Isolation of Listeria species from Faecal samples of different wild animals of Nandankanan Zoo, Barang, Odisha.

\begin{tabular}{|c|c|c|c|c|}
\hline & Species & $\begin{array}{c}\text { No. of } \\
\text { samples } \\
\text { Collected }\end{array}$ & $\begin{array}{l}\text { No. of } \\
\text { positive } \\
\text { samples }\end{array}$ & $\begin{array}{l}\text { Listeria species } \\
\text { isolated }\end{array}$ \\
\hline 1 & $\begin{array}{l}\text { Tiger } \\
\text { Panthera tigris }\end{array}$ & 19 & 4 & $\begin{array}{l}\text { L. monocytogenes } \\
\text { (3), } \\
\text { L. welshimeri (1) }\end{array}$ \\
\hline 2 & $\begin{array}{l}\text { Leopard } \\
\text { Panthera pardus }\end{array}$ & 5 & 1 & L. ivanovii (1) \\
\hline 3 & $\begin{array}{l}\text { Lion } \\
\text { Panthera leo }\end{array}$ & 8 & 2 & L. monocytogenes (2) \\
\hline 4 & $\begin{array}{l}\text { Jackal } \\
\text { Canis aureus }\end{array}$ & 2 & 1 & L. monocytogenes (1) \\
\hline 5 & $\begin{array}{l}\text { Hyena } \\
\text { Hyaena hyaena }\end{array}$ & 4 & 2 & L. monocytogenes (2) \\
\hline 6 & $\begin{array}{l}\text { Zebra } \\
\text { Equus quagga }\end{array}$ & 4 & 2 & $\begin{array}{l}\text { L. innocua (1), } \\
\text { L. seeligeri (1) }\end{array}$ \\
\hline 7 & $\begin{array}{l}\text { Elephant } \\
\text { Elephas maximus }\end{array}$ & 5 & 1 & L. monocytogenes (1) \\
\hline 8 & $\begin{array}{l}\text { Porcupine } \\
\text { Hystrix indicus }\end{array}$ & 3 & 1 & L. innocua (1) \\
\hline \multirow[t]{2}{*}{9} & $\begin{array}{l}\text { Wild Boar } \\
\text { Sus scrofa }\end{array}$ & 1 & 1 & L. innocua (1) \\
\hline & $\begin{array}{l}\text { Bear } \\
\text { Himalayan Black } \\
\text { Bear Selenarctos } \\
\text { thibetanus; } \\
\text { Sloth Bear } \\
\text { Melursus ursinus }\end{array}$ & 13 & 2 & L. inoocua (2) \\
\hline 11 & $\begin{array}{l}\text { Deer } \\
\text { Barking Deer } \\
\text { Muntiacus } \\
\text { muntjak; } \\
\text { Chital Axis axis } \\
\text { Sambar Rusa } \\
\text { unicolor; } \\
\text { Chousingha } \\
\text { Tetracerus } \\
\text { quadricornis; } \\
\text { Hog Deer } \\
\text { Hyelaphus } \\
\text { porcinus; } \\
\text { Barasinga } \\
\text { Rucervus duvaucelii }\end{array}$ & 18 & 5 & $\begin{array}{l}\text { L. monocytogenes } \\
\text { (2), } \\
\text { L. seeligeri (2), } \\
\text { L. innocua (1) }\end{array}$ \\
\hline
\end{tabular}

\begin{tabular}{|c|c|c|c|c|}
\hline & Species & $\begin{array}{c}\text { No. of } \\
\text { samples } \\
\text { Collected }\end{array}$ & $\begin{array}{c}\text { No. of } \\
\text { positive } \\
\text { samples }\end{array}$ & $\begin{array}{l}\text { Listeria species } \\
\text { isolated }\end{array}$ \\
\hline 12 & $\begin{array}{l}\text { Primate } \\
\text { Rhesus Macaque } \\
\text { Macaca mulatta; } \\
\text { Bonnet Macaque } \\
\text { Macaca radiata; } \\
\text { Assam Macaque } \\
\text { Macaca } \\
\text { assamensis; } \\
\text { Baboon Papio; } \\
\text { Nilgiri Langur } \\
\text { Semnopithecus } \\
\text { johnii; } \\
\text { Patas Monkey } \\
\text { Erythrocebus pata }\end{array}$ & 9 & 2 & $\begin{array}{l}\text { L. seeligeri (1), } \\
\text { L. welshimeri (1) }\end{array}$ \\
\hline 13 & $\begin{array}{l}\text { Blue Bull } \\
\text { Boselaphus } \\
\text { tragocamelus }\end{array}$ & 3 & 0 & - \\
\hline 14 & $\begin{array}{l}\text { Ape } \\
\text { Orangutan Pongo } \\
\text { pygmaeus; } \\
\text { Chimpanzee Pan } \\
\text { troglodytes }\end{array}$ & 4 & 0 & - \\
\hline 15 & $\begin{array}{l}\text { Rabbit Oryctolagus } \\
\text { cuniculus }\end{array}$ & 2 & 0 & - \\
\hline 16 & $\begin{array}{l}\text { Rhinoceros } \\
\text { Rhinoceros } \\
\text { unicornis } \\
\end{array}$ & 1 & 0 & - \\
\hline 17 & $\begin{array}{l}\text { Hippopotamus } \\
\text { Hippopotamus } \\
\text { amphibious }\end{array}$ & 3 & 0 & - \\
\hline & Total & 104 & 24 & $\begin{array}{l}\text { L. monocytogenes } \\
\text { (11), L. Welshimeri } \\
\text { (2), L. Ivanovii (1), } \\
\text { L. innocua (6), L. } \\
\text { Seeligeri (4) }\end{array}$ \\
\hline
\end{tabular}

$0.1 \mathrm{ml}$ of the test culture in $\mathrm{BHI}$ broth. Control eggs were inoculated with $0.1 \mathrm{ml}$ of $\mathrm{BHI}$ broth. All eggs were sealed with molten paraffin and were horizontally placed at $37^{\circ} \mathrm{C}$ for 3 days. The eggs were examined twice a day by transillumination for embryo death. A test isolate causing embryo mortality after 24 hours of inoculation was considered to be pathogenic.

Antibiotic sensitivity test: The antibiotic sensitivity of each of the Listeria isolates was tested applying the BauerKirby diffusion method (Bauer et al. 1966) using antibiotic discs (Hi-Media). The concentrations of antimicrobial agents used were as follows: levofloxacin $5 \mu \mathrm{g} / \mathrm{disc}$, enrofloxacin $5 \mu \mathrm{g} /$ disc, ciprofloxacin $5 \mu \mathrm{g} /$ disc, penicillin-G 10units/disc, amoxicillin $10 \mu \mathrm{g} / \mathrm{disc}$, chloramphenicol $30 \mu \mathrm{g} /$ disc, ceftriaxone $30 \mu \mathrm{g} / \mathrm{disc}$, cephotaxime $30 \mu \mathrm{g} /$ disc, cephadroxil $30 \mu \mathrm{g} / \mathrm{disc}$, cephalexin $30 \mu \mathrm{g} / \mathrm{disc}$, gentamicin $10 \mu \mathrm{g} / \mathrm{disc}$, oxytetracycline $30 \mu \mathrm{g} / \mathrm{disc}$, amikacin $30 \mu \mathrm{g} /$ disc, tobramycin $30 \mu \mathrm{g} /$ disc, azithromycin $30 \mu \mathrm{g} /$ disc, nalidixic acid $30 \mu \mathrm{g} /$ disc.

\section{Results}

Out of 104 examined faecal samples 24 (23.07\%) samples were found to be Listeria positive. Listeria isolates were recovered from the faecal sample of tiger, bear, hyena, leopard, zebra, elephant, jackal, lion, barking deer, porcupine, chital, monkey and wild boar. Out of 24 Listeria isolates 11 were identified as L. monocytogenes, six as $L$. innocua, four as $L$. seeligeri, two as $L$. welshimeri and one L. ivanovii (Table 1). Only four of the Listeria isolates were found to be pathogenic. These were three isolates of $L$. monocytogenes which were from tiger, hyena and elephant and one isolate of $L$. ivanovii from leopard (Table 2).

The Listeria isolates were tested in vitro for their 
Table 2. Differentiation and Pathogenicity test of Listeria isolates from faecal samples of wild animals in Nandankanan Zoo, Baranga, Odisha.

\begin{tabular}{|c|c|c|c|c|c|c|c|c|c|c|c|c|}
\hline & \multirow{4}{*}{ Animal source } & \multirow{4}{*}{ 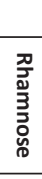 } & \multirow{4}{*}{ 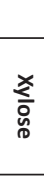 } & \multirow{4}{*}{ 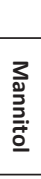 } & \multirow{4}{*}{$\begin{array}{l}3 \\
\frac{1}{0} \\
0 \\
0 \\
0\end{array}$} & \multicolumn{6}{|c|}{ Pathogenicity profile } & \multirow{4}{*}{$\begin{array}{c}\text { Species } \\
\text { identified }\end{array}$} \\
\hline & & & & & & \multicolumn{4}{|c|}{ In vitro test } & \multicolumn{2}{|c|}{ In vivo test } & \\
\hline & & & & & & \multirow{2}{*}{$\begin{array}{c}\text { Hemolysis } \\
\text { on SBA }\end{array}$} & \multirow{2}{*}{$\begin{array}{l}\text { CAMP test } \\
\text { with } S / R\end{array}$} & \multicolumn{2}{|c|}{ ALOA } & \multirow{2}{*}{$\begin{array}{l}\text { Mouse } \\
\text { lethality test }\end{array}$} & \multirow{2}{*}{$\begin{array}{c}\text { Chick } \\
\text { embrio } \\
\text { lethality }\end{array}$} & \\
\hline & & & & & & & & Colour & halo & & & \\
\hline 1 & 2 & 3 & 4 & 5 & 6 & 8 & 9 & 10 & 11 & 12 & 13 & 14 \\
\hline 1 & Tiger & + & - & - & + & + & $+S$ & BG & + & + & + & L. $m$ \\
\hline 2 & Tiger & + & - & - & + & + & $+S$ & BG & + & - & - & L. $m$ \\
\hline 3 & Tiger & + & + & - & + & - & ND & BG & - & ND & ND & L. $w$ \\
\hline 4 & Tiger & + & - & - & + & + & $+S$ & BG & + & - & - & L. $m$ \\
\hline 5 & Leopard & - & + & - & + & + & $+R$ & BG & + & + & + & L. $i$ \\
\hline 6 & Lion & + & - & - & + & + & $+S$ & BG & + & - & - & L. $m$ \\
\hline 7 & Lion & + & - & - & + & + & $+S$ & BG & + & - & - & L. $m$ \\
\hline 8 & Jackal & + & - & - & + & + & $+S$ & BG & + & - & - & L. $m$ \\
\hline 9 & Hyena & + & - & - & + & + & $+S$ & BG & + & + & + & L. $m$ \\
\hline 10 & Hyena & + & - & - & + & + & $+S$ & BG & + & - & - & L. $m$ \\
\hline 11 & Zebra & - & - & - & + & - & ND & BG & - & ND & ND & L. inn \\
\hline 12 & Zebra & - & + & - & + & + & $+S$ & BG & - & ND & ND & L. $s$ \\
\hline 13 & Elephant & + & - & - & + & + & $+S$ & BG & + & + & + & L. $m$ \\
\hline 14 & Porcupine & - & - & - & + & - & ND & BG & - & ND & ND & L. inn \\
\hline 15 & Wild Boar & - & - & - & + & - & ND & $B G$ & - & ND & ND & L. inn \\
\hline 16 & Bear & - & - & - & + & - & ND & BG & - & ND & ND & L. inn \\
\hline 17 & Bear & - & - & - & + & - & ND & BG & - & ND & ND & L. inn \\
\hline 18 & Barking Deer & + & - & - & + & + & $+S$ & BG & + & - & - & L. $m$ \\
\hline 19 & Barking Deer & + & - & - & + & + & $+S$ & BG & + & - & - & L. $m$ \\
\hline 20 & Chital & - & + & - & + & + & $+S$ & $B G$ & - & ND & ND & L. $s$ \\
\hline 21 & Chital & - & - & - & + & - & ND & BG & - & ND & ND & L. inn \\
\hline 22 & Chital & - & + & - & + & + & $+S$ & BG & - & ND & ND & L. $s$ \\
\hline 23 & Monkey & + & + & - & + & - & ND & BG & - & ND & ND & L. $w$ \\
\hline 24 & Monkey & - & + & - & + & + & $+S$ & BG & - & ND & ND & L. $s$ \\
\hline
\end{tabular}

L. m - L. monocytogenes; L. i - L. ivanovii; L. w - L. welshimeri; L. s - L. seeligeri; L. inn - L.innocua; BG - Blue Green; SBA - Sheep blood agar; CAMP - Christie- AtkinMunch- Petersen test; S/R - Staphylococcus aureua / Rhodococcus equi; ALOA - Agar Listeria according to Ottaviani and Agosti

sensitivity to different antibiotics. The obtained antibiogram revealed a high sensitivity towards ciprofloxacin and levofloxacin (100\%). High sensitivity was also observed towards amoxicillin, azithromycin (87.5\%) and enrofloxacin (79.1\%). Moderate sensitivity was observed towards chloramphenicol (66.7\%) and amikacin (58.3\%). The isolates were resistant towards oxytetracyclin, gentamycin and cephadroxil (both 75\%), penicillin-G and tobramycin (both 62.5\%), cephotaxim and cephalexin (both $45.8 \%$ ) and ceftriaxone (33.3\%). All isolates were resistant to nalidixic acid.

\section{Discussion}

Listeria monocytogenes is ubiquitous in nature and has been isolated from numerous sites, including soil, sewage water and decaying plant materials etc. Its viability is remarkable, with survival in soil or silage for more than two years. Studies have shown that about $50 \%$ of faecal samples collected from different animals like cattle, sheep, goat, pig and poultry contain $L$. monocytogenes but don't exhibit any clinical symptoms of listeriosis (Meng \& Doyle 1997; Wesley 1999). Listeria species have previously been reported in Odisha from milk samples of cows and from faecal samples of various domestic animals (Sarangi et al. 2009; Sarangi \& Panda 2012). In the present study Listeria species were isolated from 24 (23.07\%) out of 104 faecal samples of healthy zoo animals. Listeria infection is mostly food borne 
(Ryser 1999) and raw meat, vegetable and fruits used as animal feeds in zoological parks might be the major source of Listeria infections.

Listeria species have been reported from a number of wild animals in the past. L. monocytogenes have been isolated from the faecal sample of foxes, Roe Deer, badgers, hares and Pine Marten (Weis 1975), African Lion (Haigh et al. 1978), Grey Fox (Black et al. 1996), primates, hippopotamus, fox and bear (Arumugaswamy \& Gibson 1999), farm chinchilla (Sabocanec et al. 2000), captive antelopes (Bauwens et al. 2001), wild boars (Hayashidani et al. 2002), Colobus Monkey (Kock et al. 2003), jackal, Indian Fox, Sambar, wolf and Spotted Deer (Kalorey et al. 2006) and from other deer, raccoon and moose (Lyautey et al. 2007). Similarly, L. ivanovii has been isolated from Grauer's Gorilla and Red Ruffed Lemur (Bauwens et al. 2003) and from a septicaemic chinchilla (Kimpe et al. 2004). However, we isolated Listeria species from tiger, hyena, leopard, zebra, elephant, blue bull, barking deer and porcupine which all have to date not been reported to carry Listeria.

Our overall infection rate of $23.07 \%$ is comparable to infection rates found by other researchers. Bernagozzi et al. (1999) reported $24.1 \%$ of Listeria spp. in faeces of wild animals in National Park of Casentine forest (112 samples). Bauwens et al. (2001) isolated Listeria spp. from $22.8 \%$ of the faecal samples of Wild Animal Park, Planckendael (70 samples). Bauwens et al. (2003) also reported a Listeria occurrence of $21 \%$ in faecal samples of wild animals in Antwerp Zoo (200 samples). In India, Kalorey et al. (2006) isolated L. monocytogenes in $16 \%$ of faeces of wild animals (50 samples). A much lower infection rate was reported by Yoshida et al. (2000), who only found an infection rate of $6.1 \%$ (623 samples) in all animals tested. However in Japanese macaques the infection rate was also $20 \%$. Recently, Yadav et al. (2011) isolated two Listeria species (L. monocytogenes and $L$. innocua) out of three positive isolates from 56 faecal samples collected from mammals and birds at Baroda Zoo, Vadodara, Gujarat State, India, which equals to a prevalence of only $5.3 \%$. However as the range of species and animals examined in these studies are entirely different it is not possible to conclusively compare the infection rates found.

In the present study 11 (10.57\%) L. monocytogenes were isolated which differ from the observation of Arumugaswamy \& Gibson (1999) who after examination of 86 animals of Taronga Zological Garden, New South Wales, Australia, revealed $25.6 \%$ were carrier of Listeria species and $18.6 \%$ were excreting $L$. monocytogenes. This difference may be due to varying environmental condition between different locations, previous occurrence of the disease and hygienic measures adopted in the zoo.

Listeria spp. have in the past been reported to be sensitive to antibiotics active against gram positive bacteria (Hawkins et al. 1984), but some time later reports of resistance in Listeria spp. appeared (Abrahim et al. 1998; Walsh et al. 2001). An increase in antibiotic resistance in Listeria spp. is in line with a global pattern of an increasing antibiotic resistance, including resistances against multiple antibiotics in many groups of bacteria. The occurrence of antibiotic resistance in non-pathogen forms poses a major risk as there is possibility to transfer the resistance factor from non-pathogens to pathogenic organisms (Walsh et al. 2001).

In our study we found high to moderate sensitivity towards ciprofloxacin, levofloxacin, amoxicilin, azithromycin,enrofloxacin, chloramphenicolandamikacin and resistance towards oxytetracyclin, gentamycin, cephadroxil, penicillin-G, tobramycin, cephotaxim, cephalexin, ceftriaxone and nalidixic acid. Similar results have been reported by Lyautey et al. (2007) who found resistance against kanamycin, gentamycin, streptomycin and rifampicin. This differs from findings of Butko et al. (1972), who reported the sensitivity of Listeria spp. to erythromycin, chlortetracycline, streptomycin, levomycin, neomycin and monomycin and resistance to penicillin. This variation in antibiotic sensitivity might be due the above mentioned global increase in antibiotic resistance in the bacteria over decades.

The present study shows the occurrence of Listeria species in captive wild animals of Nandankanan Zoo, Baranga, Odisha, which may act as nidus of infection for other susceptible animals and cause death of animals. A further study investigating the role of Listeria in sick wild animals is necessary and emphasis should be given to control the food borne transmission of the diseases.

\section{REFERENCES}

Abrahim, A., A. Papa, N. Soultos, I. Ambrosiadis \& A. Antoniadis (1998). Antibiotic resistance of Salmonella spp. and Listeria spp. isolates from traditionally made fresh sausages in Greece. Journal of Food Protection 61: 1378-1380.

Arumugaswamy, R. \& L.F. Gibson (1999). Listeria in zoo animals and rivers. Australian Veterinary Journal 77(12): 819-820.

Bauer, A.W., W.M.M. Kirby, J.C. Sherris \& M. Turck (1966). Antibiotic susceptibility testing by a standardized single disc method. American Journal of Clinical Pathology 45: 493-496.

Bauwens, L., F. Vercammen \& A. Hertsens (2003). Detection of pathogenic Listeria spp. in zoo animal faeces: use of immunomagnetic separation and a chromogenic isolation medium. Veterinary Microbiology 91(2/3): 115-123.

Bauwens, L., F. Vercammen \& W. de. Meurichy (2001). Occurrence of Listeria spp. in captive antelope herds and their environment. 
Journal of Zoo and Wildlife Medicine 32(4): 514-518.

Bernagozzi, M., R. Sacchetti, O. Varoli \& A. Nanetti (1999). Yersinia, Listeria, Campylobacter and Salmonella in faeces of wild mammals. Igiene Moderna 112(2): 519-542.

BIS (Bureau of Indian Standards) (1994). Committee Draft, Genera guidance for the detection of Listeria monocytogenes. Microbiology CD: 11290, 11-12.

Black, S.S., F.W. Austin \& E. McKinley (1996). Isolation of Yersinia pseudotuberculosis and Listeria monocytogenes serotype 4 from a gray fox (Urocyon cinereoargenteus) with canine distemper. Journal of Wildlife diseases 32(2): 362-266.

Butko, M.P., V.N. Dyadechko, M.D. Domatskaya, A.V. Kulikovskii \& Z.I. Pilipets (1972). Isolation and properties of Listeria monocytogenes from wild animals in western Siberia. Problemy Veterinarnoi Sanitarii 42: 86-100.

Haigh, J.C., J.W. Pharr \& P.Y. Daoust (1978). Pleuro-pericarditis and pneumonia due to Listeria monocytogenes in an African lion. Journal of Zoo Animal Medicine 9(2): 38-42.

Hawkins, A.E., R. Bortolussi \& A.C. Issekutz (1984). In vitro and in vivo activity of various antibiotics against Listeria monocytogenes type 4b. Clinical and Investigative Medicine 7: 335-341.

Hayashidani, H., N. Kanzaki, Y. Kaneko, A.T. Okatani, T. Taniguchi, K. Kaneko \& M. Ogawa (2002). Occurrence of yersiniosis and listeriosis in wild boars in Japan. Journal of Wildlife Diseases 38(1): 202-205.

Kalorey, D.R., N.V. Kurkure, S.R. Warke, D.B. Rawool, S.V.S. Malik \& S.B. Barbuddhe (2006). Isolation of pathogenic Listeria monocytogenes in faeces of wild animals in captivity. Comparative Immunology Microbiology and Infectious Diseases 29(5-6): 295-300.

Kimpe, A., A. Decostere, K. Hermans, M. Baele \& F. Haesebrouck (2004). Isolation of Listeria ivanovii from a septicaemic chinchilla (Chinchilla lanigera). Veterinary Record 154(25): 791-792.

Kock, N.D., R.A. Kock, E. Wambua and K. Mohan (2003). Listeriosis in a free ranging colobus monkey (Colobus guereza caudatus) in Kenya. Veterinry Record 152(5): 141-142.

Low, J.C. \& W. Donachie (1997). A review of Listeria monocytogenes and listeriosis. The Veterinary Journal 153: 9-29.

Lyautey, E., A. Hartmann, F. Pagotto, K. Tyler, D.R. Lapen, G. Wilkes, P. Piveteau, A. Rieu, W.J. Robertson, D.T. Medeiros, T.A. Edge, V. Gannon \& E. Topp (2007). Characteristics and frequency of detection of fecal Listeria monocytogenes shed by livestock, wildlife and humans. Canadian Journal of Microbiology 53(10): 1158-1167.

Malik, S.V.S., S.B. Barbuddhe, S. Das, S. Shoukat \& D.P. Das (2010). Current Advances in Diagnosis of listeriosis, pp. 10-20. In: Newer Concepts in Diseases of Animal, Farm Animals, Poultry, Wildlife and Laboratory Animal Diseases. Compendium of ICAR Winter School organised by Division of Pathology, IVRI, Izatnagar.

McClain, D., \& W.H. Lee (1988). Development of USDA-FSIS method for isolation of Listeria monocytogenes from raw meat and poultry. Journal - Association of Official Analytical Chemists 71: 660-664.

McKellar, R.C. (1994). Use of the CAMP Test for Identification of Listeria monocytogenes. Applied and Environmental Microbiology 60(12): 4219-4225

Meng, J., \& M.P. Doyle (1997). Emerging issues in microbiological food safety. Annual Review of Nutrition 17: 255-275.
Menudier, A., C. Bosiraud \& J.A. Nicolas (1991). Virulence of Listeria monocytogenes serovars and Listeria spp. in experimental infection of mice. Journal of Food Protection 54: 917-921.

Notermans, S., J. Dufrenne, T. Chakraborty, S. Steinmeyer \& G. Terplant (1991). The chick embryo test agrees with the mouse bioassay for assessment of the pathogenicity of Listeria species. Letters in Applied Microbiology 13: 161-164.

Ryser, E.T. (1999). Food borne listeriosis, pp. 299-358. In: Ryser, E.T. \& E.H. Marth (ed.). Listeria, Listeriosis and Food Safety. Marcel Dekker Inc., New York.

Sabocanec, R., K. Culjak, K. Ramadan, T. Naglic, B. Seol \& D. Maticic (2000). Incidence of listeriosis in farm chinchillas (Chinchilla laniger) in Croatia. Veterinarski Arhiv 70(3): 159-167.

Sarangi, L.N. \& H.K. Panda (2012). Isolation, Characterization and Antibiotic sensitivity test of pathogenic Listeria species in livestock, poultry and farm environments of Odisha. Indian Journal of Animal Research 46(3): 242-247.

Sarangi, L.N., H.K. Panda, A. Priyadarshini, S. Sahoo, T.K. Palai, S. Ranabijuli, S. Senapati \& D.N. Mohanty (2009). Prevalence of Listeria species in milk sample of cattle of Orissa. Indian Journal of Comparative Microbiology Immunology and Infectious Diseases 30 (2): 135-136.

Seeliger, H.P.R. \& D. Jones (1986). Genus Listeria. pp. 1235-1245. In: Sneath, P.H.A. (ed.). Bergey's Manual of Systematic BacteriologyVol. 2. Williams and Wilkins, Baltimore, MD.

Sheehan, B., C. Kocks, S. Dramsi, E. Gouin, A.D. Klarsfeld, J. Mengaud \& P. Cossart (1994). Molecular and genetic determinants of the Listeria monocytogenes infectious process. Current Topics in Microbiology and Immunology 192: 187-216.

Sonnenworth, A.C. (1980). Listeria monocytogenes. Gradwohl's Clinical Laboratory Methods and Diagnosis, pp. 1673-1692. In: Sonnenworth A.C. and L.C.V. Jarett (ed.). Mosby Company, London.

Walsh, D., G. Duffy, J.J. Sheridan, I.S. Blair \& D.A. McDowell (2001). Antibiotic resistance among Listeria, including Listeria monocytogenes, in retail foods. Journal of Applied Microbiology 90: 517-522.

Weis, J. (1975). The incidence of Listeria monocytogenes in domestic and wild animals in South-West Germany, pp. 121-126. Abst Paper In: Problems of listeriosis Proceedings of the sixth International Symposium. Faculty of Agricultural Science, University of Nottingham.

Wesley, I.V. (1999). Listeriosis in animals, pp. 39-73. In: Ryser, E.T. \& E. H. Marth (ed.). Listeria, Listeriosis and Food Safety. Marcel Dekker Inc., New York, N.Y.

Yadav, M.M., A. Roy, B. Bhanderi \& R.G. Jani (2011). Prevalence of Listeria species including L. monocytogenes from apparently healthy animals at Baroda Zoo, Gujarat State, India. Journal of Threatened Taxa 3(7): 1929-1935.

Yoshida, T., T. Sugimoto, M. Sato \& M. Hirai (2000). Incidence of Listeria monocytogenes in Wild Animals in Japan. Journal of Veterinary and Medical Science 62(6): 673-675. 